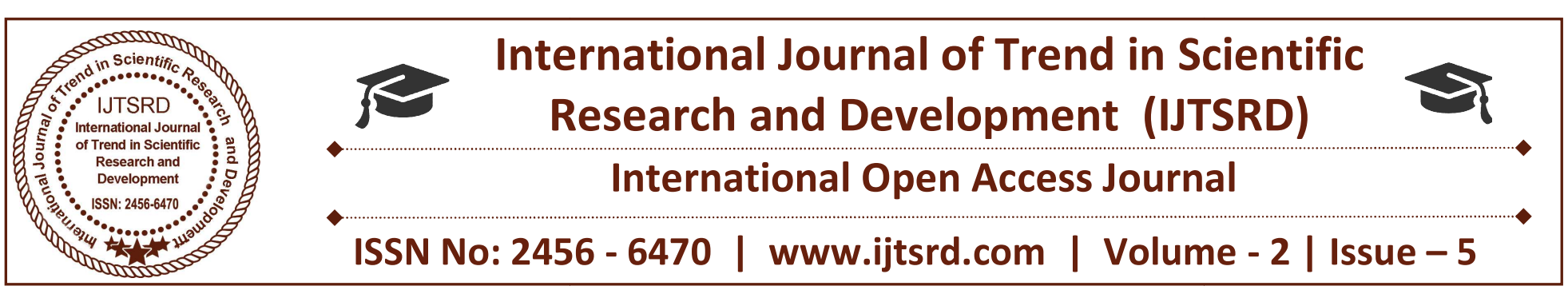

\title{
Use of Rice Husk Ash as an Admixture to Substitute of Portland Cement in Concrete
}

\author{
Asif Farooq ${ }^{1}$, Mr. Misba Danish ${ }^{2}$ \\ ${ }^{1}$ Student, ${ }^{2}$ Assistant Professor \\ Department of Civil Engineering, Al-Falah School of Engineering and Technology \\ Al-Falah University, Faridabad, Haryana, India
}

\section{ABSTRACT}

The increase in rate of construction increases the rate demand of Portland cement now a day. Due to urbanization it is estimated that the production of cement increase up to 200 million ton in 2015. Being development of nation on one side, the side effect grows in form of global warming. Increased rate of industrialization leads to Production of toxic gases like $\mathrm{CO}, \mathrm{CO} 2$, and other hazardous gases leads to ozone depletion which is main cause of global warming \& a threat to environment. $\mathrm{CO} 2$ gas contributes in relation to $63.33 \%$ of global warming. The factories which manufacture cement $S$ are responsible for a quantity of the $\mathrm{CO} 2$ gas production because the production of one ton of Portland cement emits around one ton of $\mathrm{CO} 2$ into the ambiance. To eliminate the main cause of global threat (CO2), the new idea came in to existence i.e. use of substitute materials in construction industry. For this purpose, the uses of industrial dissipate products and agricultural by products are very beneficial. These industrial dissipate and agricultural by products such as Silica Fume, Rice Husk Ash, Slag, and Fly Ash etc, are capable of used as cementing materials due to their pozzolanic behavior, these products require large tract of lands for dumping. Great amount of dissipate achieve as by products from several of the industries can be the main sources of such alternate materials. The world rice crop is estimated at 596 million tons per year and India is second major producer of rice in the world with yearly production of 146 million tons per year.

The RICE HUSK ASH (RHA) can be utilize as a substitute material as replacement for ordinary Portland cement. This technology may possibly decrease the $\mathrm{CO} 2$ discharge to the environment caused by the cement industries.

In the present study, a possibility has completed to use of Rice Husk Ash as an admixture to substitute of Portland cement in concrete, and an effort has been made to explore the strength parameter of concrete. For control concrete, IS method of mix design has taken on and considering this a basis, mix design for replacement technique has been finished. Five dissimilar replacement levels 5\%, 7.5\%, 10\%, 12.5\% and $15 \%$ are selected for the study concern to replacement method with range of curing stage starting from 7 days and 28 days are considered in the present study. The water/cement ratio used in this study is 0.40 .

The all results were compared to concrete without RHA. The compressive, split tensile and flexural strength were compared with those concrete without RHA. The results show that the rice husk ash gives the good performance on compressive, split tensile and flexural strength at the age of 28 days of curing. The results were evaluated with the concrete without RHA. The saturated water absorption results shows that the percentage of water absorption of concrete with containing 7.5-12.5\% replacement of cement by RHA is decrease as compare to concrete without containing RHA.

\section{INTRODUCTION}

The rice husk is the residual material produced during milling process of paddy. The outer covering of paddy grain is surrounded by the byproduct known as husk when burning of this rice husk is done in proper 
manner in a furnace, the rice husk ash is obtained. In the burning process of rice husk, this husk has approximate $75 \%$ organic volatile substance and remaining $25 \%$ weight of husk is transformed into ash and this ash is known as rice husk ash (RHA). The RHA contains about $80-90 \%$ amorphous silica. In every $1000 \mathrm{~kg}$ of paddy, approximate $25 \%(250 \mathrm{~kg})$ of husk is produced, and around $75 \%(750 \mathrm{~kg})$ of rice is produce. In the milling process when this husk is burnt in the boiler approximate $25 \%(55 \mathrm{~kg})$ of rice husk ash is produced.

Rice husk ash acts as a Pozzolanic material which have reactive high silica or alumina, which have little or no binding property, but when this pozzolanic materials react with lime in the presence of water, it will set and become harden like ordinary Portland cement. Pozzolanic materials are best alternative which substitute cementing material instead of ordinary Portland cement. Pozzolanas can be intermingling with OPC for improving the strength and durability of concrete. The pozzolanic material reduces the cost of construction.

From the industrial and agriculture waste a wide variety of siliceous or aluminous materials may be pozzolanic. The rice husk is commonly available from the agriculture waste and is has the greatest potential, after burning of rice husk in rice mill produce large amount of ash which contain high amount of silica $(90 \%)$. India is a second major country which producing rice, and the huge quantity of husk is produce during milling process of paddy. In India annually approximate 20 million ton of rice husk ash is produced. From 5 ton of rice paddy about one ton husk is produced. The yearly production of RHA is about 20 ton.

Burning of Rice husk ash should be done in proper manner.

At the temperature $550^{\circ} \mathrm{C}-800^{\circ} \mathrm{C}$ amorphous silica is produced and after the $800^{\circ} \mathrm{C}$ (at high temperature), crystalline silica is formed. The properties of amorphous silica are different from crystalline silica so it is important to make the desire temperature to get the correct specification for the particular end use. In this study the ordinary Portland cement is replaced by RHA at different proportion such as $5 \%, 7.5 \%, 10 \%$, $12.5 \%$ and $15 \%$ to study different strength properties, saturated water absorption of concrete and comparison of strength at different age of curing.

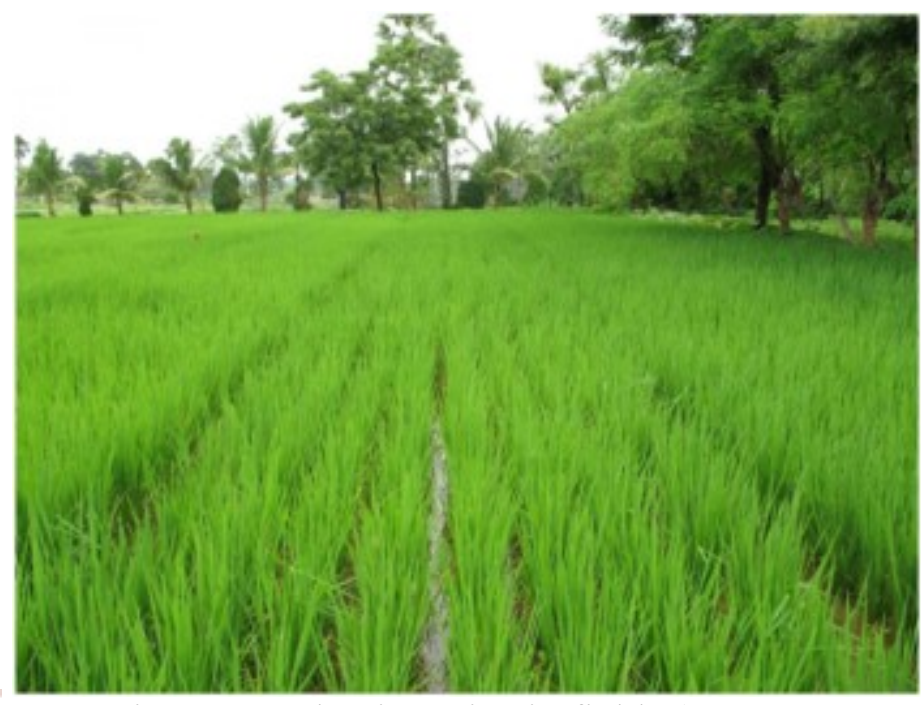

Figure 1.1 Planting Rice in fields (Sourcewww.rkmp.co.in)

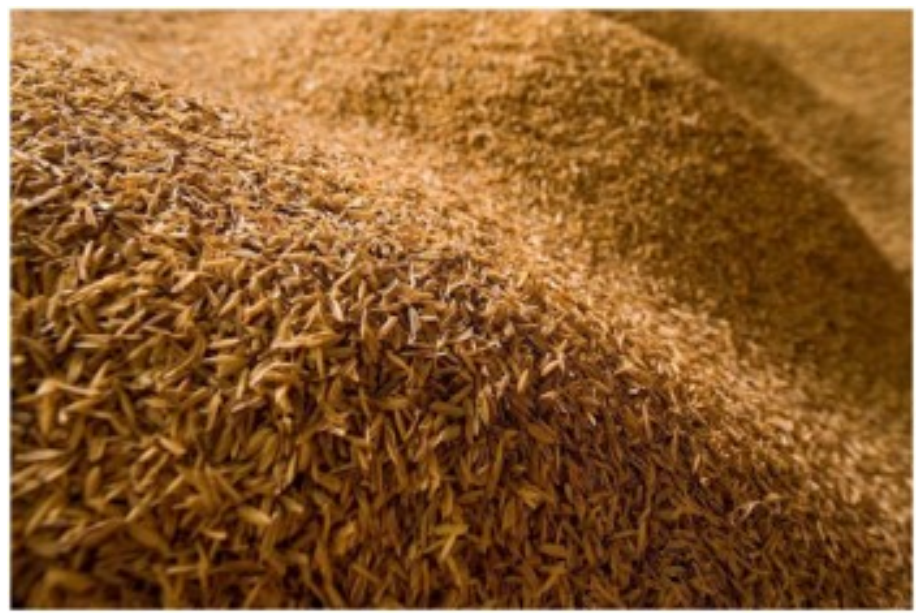

Figure 1.2 Rice Husk after the milling process of paddy (Source-https://commons.wikimeadia.org)

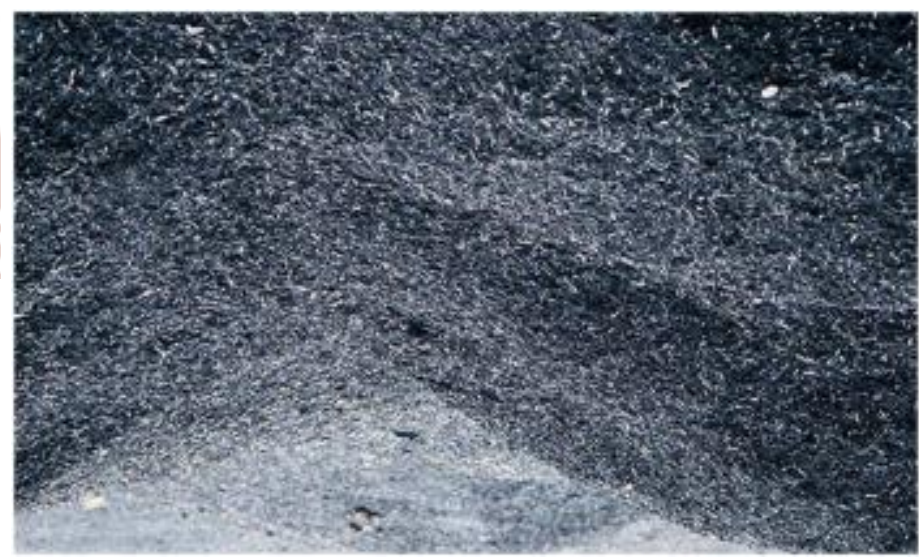

Figure 1.3 RHA after the burning of rice husk in boiler (Source- www.ceoriceoil.com)

\section{JUSTIFICATION OF THE STUDY}

Rice husk is the residual material after milling process of paddy usually dumped or burned, which may cause to environmental problems like air pollution \& damage to land on which it is dumped. By this study 
we can use rice husk ash as a cementitious material in construction industry because of their pozzolanic behavior. Rice husk ash contain high amount of silica $\&$ by the use of rice husk ash as a cementitious material with partially replacement of cement it gives high strength concrete and durable concrete. Use of rice husk ash can reduce the environmental problem such as ash fly in air and substitute the problem of land for dumping. When the cement is prepared the $\mathrm{CO} 2$ emit in large amount so we can use rice husk ash as cementitious material to reduce the $\mathrm{CO} 2$ gas which is responsible for global warming.

IMPORTANCE IN CONSTRUCTION / CIVIL ENGINEERING

$>$ Rice husk ash improves strength of concrete.

$>$ Use of RHA with cement improves stability.

$>$ Rice husk ash reduces heat evolution.

$>$ Rice husk ash blocking the large voids in the hydrated cement paste through pozzolanic reaction.

$>$ Rice husk ash decreases permeability of concrete.

$>$ Rice husk ash modifies physical and thermo physical properties of concrete.

$>$ Surface area of RHA in concrete does not decrease with increasing temperature.

\section{OBJECTIVE OF THE PROJECT}

The aim of the present investigation is:

$>$ To study different strength properties compressive Strength, flexuralstrength and split tensile strength of Rice husk ash concrete with age in comparison to Control concrete.

$>$ To study the relative strength development with age of Rice husk ash concrete with Control concrete of same grade.

$>$ To determine the optimum level of replacement of ordinary Portland cement with rice husk ash.

$>$ To determine the initial setting time and final setting time of rice huskash concrete.

$>$ To determine the workability of Rice husk ash concrete with super plasticizer. To conduct durability study on Rice husk ash concrete with mineral admixtures.

\section{SCOPE OF THE PROJECT}

$>$ The Experimental investigation is planned as under:

$>$ To obtain Mix proportions of Control concrete by IS method.

$>$ To conduct Compression test on RHA concrete and control concrete on standard IS specimen size 150x150x150 mm.

$>$ To conduct split tensile test on RHA concrete and control concrete on standard IS specimen size 150x300 mm.

$>$ To conduct Flexural test on RHA concrete and Control concrete on standard IS specimen size 100 $\mathrm{x} 100 \times 500 \mathrm{~mm}$.

$>$ To conduct durability test on RHA concrete on standard IS specimen size 100x100x100 mm.

\section{LITERATURE REVIEW}

\section{Chai Jaturapitakkul and Boonmark Roongreung (2003)}

In this study the researcher suggest a new cementitious material from a mixture of $50 \%$ rice husk ash and 50\% calcium carbide residue. This mixture shows cementing property and identify as a pozzolanic reaction between the two materials without $\mathrm{OPC}$ in the mixture. In this study the different properties such as compressive strength and flow were investigated when rice husk ash and calcium carbide residue were used as a cementitious material. In this study the setting time of new material is greater than the OPC paste. The highest compressive strength of mortar is obtained by the ratio of RHA and CCR of 50:50 by the weight at curing age of 28 days. The mixture from CCR and RHA has a high potential to be used as a cementing material according to compressive strength of mortar.

\section{Deepa G. Nair , K.S. Jagadish, Alex Fraaij (2006)}

This study shows the RHA was produce by the different types of field oven and the property were discussed in this paper. The performance of oven has discussed to classify most suitable method to produce reactive pozzolanic material as a substitute of cement for the low strength of conduction application. The long term strength of RHA pozzolanas with lime or cement is investigated to recommend a sustainable reasonable opportunity in rural construction applications.

\section{Gemma Rodri'guez de Sensale (2006)}

This study gives the information about the improvement of compressive strength of concrete with RHA at the age of 91 days. In this study two different replacement of cement were used by RHA $10 \%$ and $20 \%$. Three different water/cement ratios were used in this study $0.50,0.40$ and 0.32 . The all results are compared to concrete without RHA. The compressive, split tensile strength and air 
permeability are compared with those concrete without RHA. The results show that the residual rice husk ash gives the good performance on compressive strength but the long term behavior of concrete with rice husk ash produces by proscribed burning was more important. The splitting tensile and air permeability results show that the burning temperature of RHA should be in control manner.

\section{Gemma Rodríguez de Sensale (2010)}

This paper discuss about the influence on durability aspects by the partially replacement of OPC by RHA and the investigation has done on high performance cementitious materials. Two RHAs (amorphous and partially crystalline optimized by dry-milling) and different water-cementitious materials ratio and different percentages of RHA replacement levels are investigated in this study. The durability aspects were tested namely air permeability, chloride ion penetration, alkali-silica expansion, sulfate and acid resistance. The result was evaluated with the concrete without RHA. It is concluded from the tested properties that the incorporation of both RHAs in concretes explain different behaviors for chloride ion penetration and air permeability depending on the water-cementitious materials ratio. In mortars, it reduces the mass loss of specimens exposed to hydrochloric acid solution and decreases the expansion due to sulfate attack and the alkali-silica reaction.

\section{Hwang Chao-Lung, Bui Le Anh-Tuan, Chen Chun-Tsun (2011)}

This study shows the influence of partially replacement of cement by RHA derived from the South Vietnam produced by burring of rice husk in the boiler. For improvement of pozzolanic reactivity of RHA it is ground for 1 hour. The ground RHA and non-ground RHA were investigate to check the strength. The different types of properties were investigated in this study include compressive strength, concrete electrical resistivity, and ultrasonic pulse velocity. In the testing of concrete some properties were investigated compressive strength, concrete electrical resistivity, and ultrasonic pulse velocity. After the testing of concrete the results explain that the non-ground RHA can be applied as a pozzolanic material. The smallest particle size of ground RHA increases the compressive strength of concrete. After the testing of concrete the result shows that the RHA can be used up to $20 \%$ with cement without adversely affecting the strength and durability properties of concrete.

\section{Rahmat Madandoust, Malek Mohammad Ranjbar, Hamed Ahmadi Moghadam, Seyed Yasin Mousavi (2011)}

In this paper the influence of RHA on concrete properties and durability aspect were studied. To determine the appropriate percentage of rice husk ash for partial replacement of OPC, mixture with $0-30 \%$ rice husk ash and test were established and mechanical properties were determined. The durability test was conduct in aggressive environment $5 \% \mathrm{Nacl}$ with wet dry cycling, was assess for 11 months.

The degree of damage was considered by determining the percentage of decrease in compressive strength and chloride ions penetration as compare with control specimens. The result shows that the partial replacement of cement by rice husk ash enhanced durability and homogeneity but did not increase the early age compressive strength of concrete.

7. M.F.M. Zain, M.N. Islam, F. Mahmud, M. Jamil (2011)

This paper discuss about production procedure of RHA from rice husk and the quality of RHA produced using rudimentary oven of the National University of Malaysia. Two grinding methods and three combustion methods were used to determine the physical properties and chemical aspects of RHA produced.

Combustion temperature distribution of the furnace, silica crystallization phase, ash particle size, and chemical content of the produced RHA were considered using $\mathrm{X}$ - ray diffraction analysis and scanning electron microscopy. The test results shows that the combustion period, chilling duration, and grinding process and duration are essential in obtaining RHA of standard fineness and quality. Air ducts in the furnace are extremely useful in order to provide air for appropriate burning of rice husk

\section{S. BAHRI, H. B. MAHMUD (2013)}

This study gives the good technical option of using rice husk ash to produce high performance concrete of $100 \mathrm{MPa}$. The variables of study consist of level of cement replacement by RHA and effect of grinding of RHA. The fine aggregate used was mining sand as an alternative of silica sand which is commonly used in 
producing high performance concrete. The level of cement replacement by RHA was at $0 \%, 10 \%, 15 \%$ and $20 \%$ and the particle size of the RHA used was $13.50 \mu \mathrm{m}, 20.43 \mu \mathrm{m}$ and $29.92 \mu \mathrm{m}$. The results show that the use of $10 \%$ RHA with the average particle size of $20.43 \mu \mathrm{m}$ gave better compressive strength from 3 days onwards compared to control OPC and silica fume and the use of $20 \%$ of RHA with the average particle size of $13.50 \mu \mathrm{m}$ at 28 days gave better compressive strength compared to control OPC and silica fume.

\section{Ha Thanh Le, Sang Thanh Nguyen, and Horst- Michael Ludwig (2014)}

It is an experimental study of the influence of partially replacement of cement by RHA on strength and durability and workability, of high performance finegrained concrete. The results show that the replacement of cement with RHA to HPFGC improved splitting tensile strength, compressive strength and chloride penetration resistance. In this study the results are shows that the ratio of compressive strength to splitting tensile strength of high performance fine-grained concrete was lower than that of normal concrete, especially for the concrete made with $20 \%$ RHA. Compressive strength and splitting tensile strength of HPFGC containing RHA was similar and a little higher, than for HPFGC containing SF.

\section{METHODOLOGY}

Experimental

The nature of this study is based on experimental program. This study will focus on standard concrete of M40 concrete grade with characteristic strength of $40 \mathrm{~N} / \mathrm{mm} 2$ at 28 days with ingredients of Ordinary Portland cement and rice husk ash at different percentages such as $0,5,7.5,10,12.5,15$ percent as binder, $20 \mathrm{~mm}$ coarse aggregate and river sand, Conplast SP430 G8 as a superplasticizer. Different percentage of rice husk ash will use as a partially replacement of cement and superplasticizer will use for improve workability. The percentage of superplasticizer will depend upon the workability of concrete. The superplasticizer doses also depend upon the percentage replacement of cement by rice husk ash without loss of workability. By the use of different percentage of rice husk ash in OPC the optimum value of replacement can be find by the compressive strength, split tensile strength and flexural strength of concrete. The compressive strength, split tensile strength, flexural strength test will be on universal testing machine with mold of cube, cylinder and beam respectively at 7 days and 28 days.

The process of this experimental study is given below:

$>$ Study of literature

$>$ Procurement of materials

$>$ Testing of materials

$>$ Mix design

$>$ Casting of specimens

$>$ Curing of specimens

$>$ Testing of specimens

$>$ Analyses of different strength at different age

> Analyses the optimum level of R.H.A \& Conclusion of the study

METHODOLOGY USED TO ANALYSE THE OPTIMUM QUANTITY OF R. H. A AND STUDY COMPARISION OF STRENGT CHARACTERISTICS ARE GIVEN FOLLOWING.
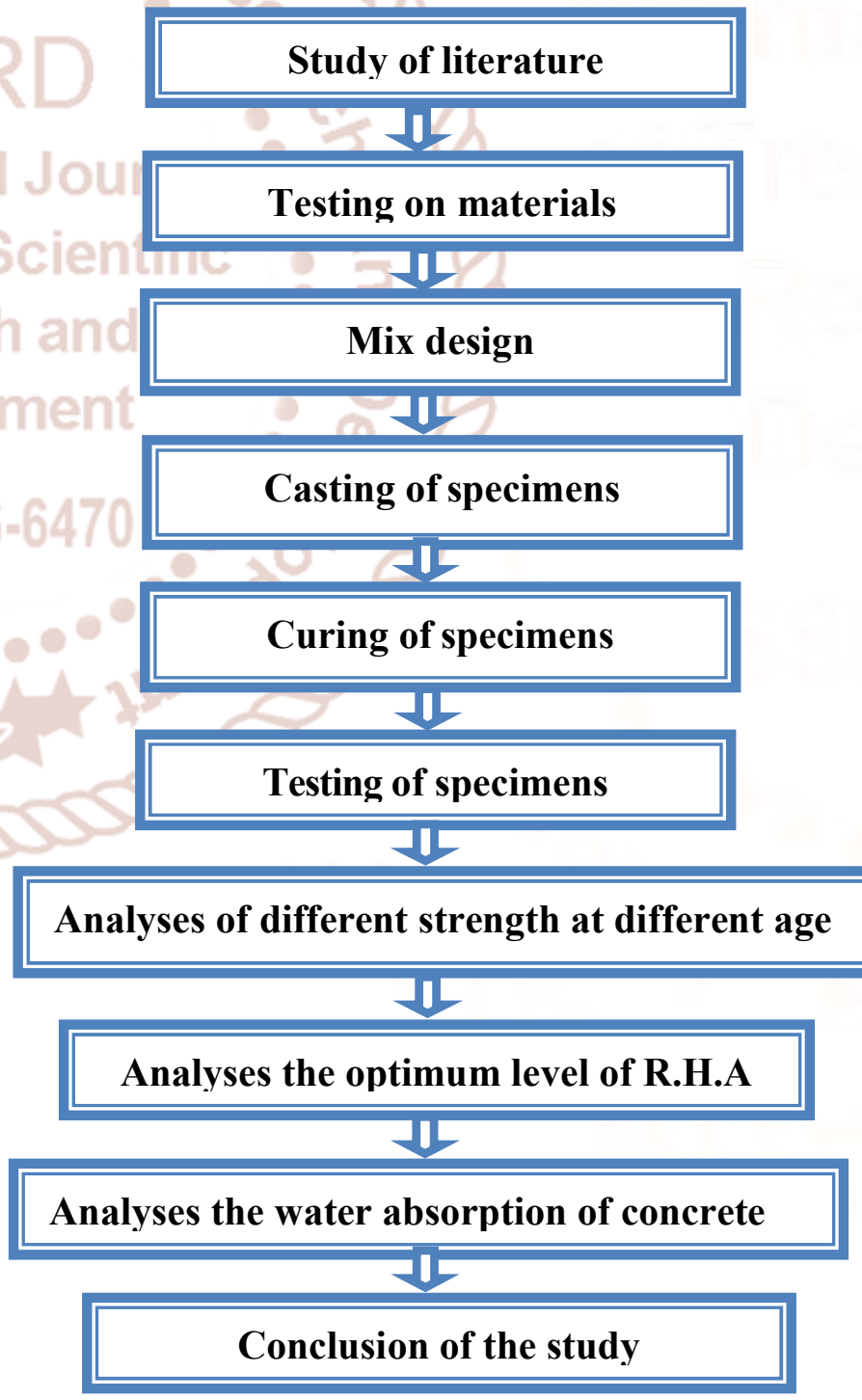
International Journal of Trend in Scientific Research and Development (IJTSRD) ISSN: 2456-6470

\section{MATERIALS USED}

Rice Husk Ash

Rice Husk Ash used in the present experimental study was obtained from KRBL RICE MILL Ghaziabad, U.P. Specifications and Physical Properties and of this RHA are given in Table 4.1 and 4.2.

Table 4.1 Specification of procured Rice Husk Ash

\begin{tabular}{|c|c|}
\hline \multicolumn{2}{|c|}{ Specifications of Rice Husk Ash } \\
\hline Silica & $90 \%$ minimum \\
\hline Water absorption & $2 \%$ maximum \\
\hline Mean Particle Size & 25 microns \\
\hline Color & Grey \\
\hline
\end{tabular}

Table 4.2 Physical properties of procured Rice Husk Ash

Physical properties of Rice Husk Ash

\begin{tabular}{|c|c|}
\hline Physical State & Solid - Non Hazardous \\
\hline Appearance & Very fine powder \\
\hline Particle Size & 25 microns - mean \\
\hline Color & Grey 1 rrnati \\
\hline Odor & Odorless \\
\hline Specific Gravity & 2.3 \\
\hline
\end{tabular}

\section{CHEMICAL COMPOSITION TEST}

The chemical analysis of sample was carried out at

\section{SAIFCO cement industries}

cement plant and following result was obtained.

Table 4.3 Chemical composition of Rice Husk Ash

\begin{tabular}{|c|c|}
\hline Constituents & Percentage \\
\hline $\mathrm{SiO} 2$ & 86.81 \\
\hline $\mathrm{Al} 2 \mathrm{O} 3$ & 0.50 \\
\hline $\mathrm{Fe} 2 \mathrm{O} 3$ & 0.87 \\
\hline $\mathrm{CaO}$ & 1.04 \\
\hline $\mathrm{MgO}$ & 0.85 \\
\hline $\mathrm{Na} 2 \mathrm{O}$ & 0.69 \\
\hline $\mathrm{K} 2 \mathrm{O}$ & 3.16 \\
\hline $\mathrm{LOI}$ & 4.6 \\
\hline
\end{tabular}

\section{CEMENT}

Cement used in this project work is Ordinary Portland Cement of 53 Grade (KHYBER CEMENT) conforming to IS: 12269-2013 of specific gravity
3.15. The physical properties of the cement obtained on conducting appropriate tests and the requirements as per IS: $12269-2013$ is given in Table 4.4.

\section{Table 4.4 Physical properties of Ordinary Portland} Cement

\begin{tabular}{|c|c|c|}
\hline Particulars & $\begin{array}{c}\text { Test } \\
\text { Results }\end{array}$ & $\begin{array}{c}\text { Requirements } \\
\text { of IS: } \\
\mathbf{1 4 8 9 - 1 9 9 1}\end{array}$ \\
\hline Specific Gravity & 3.15 & \\
\hline $\begin{array}{c}\text { Setting Time } \\
\text { (Minutes):Initial }\end{array}$ & $180 \mathrm{Min}$ & $30 \mathrm{Min}$ \\
Final & $280 \mathrm{~min}$ & 600 \\
\hline
\end{tabular}

\section{AGGREGATES}

\section{Fine Aggregate}

Fine aggregate was purchased which satisfied the required properties of fine aggregate required for experimental work and the sand conforms to zone II as per the specifications of IS 383: 1970.
A. Specific gravity $=2.63$
B. Fineness modulus $=2.587$

\section{COARSE AGGREGATE}

Crushed granite of $20 \mathrm{~mm}$ maximum size has been used as coarse aggregate. The sieve analysis of combined aggregates confirms to the specifications of IS 383: 1970 for graded aggregates.

A. Specific gravity $=2.67$

\section{SUPER PLASTICIZER}

The most important chemical admixture is the super plasticizer, which is the High- Range Water-Reducing Admixture (HRWRA). There are four types of super plasticizers name sulphonated malanie-formaldehyde, sulphonated naphthalene formaldehyde, modified lignosulphonated and other types Super plasticizers are water reducers which are capable of reducing water content by about 30 percent. For this present investigation, a super plasticizer that is CONPLAST SP430 G8 has been used for obtaining workable concrete.

Sulphonated naphthalene formaldehyde polymer is a major component of the super plasticizer used here. It take place in neutralizing the surface charges on the cement particles and enhancing water tied up in the cement agglomerations and thereafter reducing the viscosity of the paste and concrete. It promotes dispersing of cement particles and reduces water requirements without affecting the workability, thus 
resulting high-strength concrete and lower permeability. Super plasticizers are linear polymers containing sulfonic acid groups or carboxylic groups attached to the polymer backbone at regular intervals.

\section{CONPLAST SP430 G8}

This chemical super plasticizing admixture manufactured by "FOSCROC Chemicals" used in this project. The main objective of using this super plasticizer is to produce high workability concrete requiring little or no vibration during placing. Conplast SP430 G8 is based on Sulphonated Naphthalene formaldehyde and obtained as a brown liquid instantly dispersible in water. Conplast SP430 G8 has specially formulated to give high water reductions up to $25 \%$ without loss of workability or to produce high quality concrete of reduced permeability.

\section{PROPERTIES}

Specific gravity: $1.265-1.280$ at $27{ }^{\circ} \mathrm{C}$

Chloride content: NIL

Air entrainment: Approximate 1\% over control

\section{WATER}

Water is an essential constituent of concrete as it actively participate in the chemical reaction with cement. It is help to form the strength giving cement gel. The quality and quantity is very important and it should be taken very carefully. Quality of water affects the strength, it is necessary for experimental work to go into purity and quality of water. Water takes part in the chemical reactions with cement to form the hydration product, calcium- silicate-hydrate (C-S-H) gel. Some specification also accept water for making concrete if the $\mathrm{pH}$ value of water lies between 6 and 8 and the water is free from organic matter. Carbonates and bi-carbonates of sodium and potassium effect the setting time of cement. While sodium carbonate may cause quick setting time, the bi- carbonates may either accelerate or retard the setting. The other higher concentration of these salts will materially reduce the concrete strength.

\section{PRODUCTION OF RICE HUSK ASH}

The RHA produce from the burning of husk in boiler at controlled temperature that fulfils the physical characteristics and chemical composition of mineral admixtures. The pozzolanic behavior of RHA depends upon the silica crystallization phase, silica content and size and surface area of ash. The amount of carbon content in RHA should be smallest. If the carbon contain is more in RHA the strength of concrete will be less. RHA is produce by burning of rice husk at control temperature that has amorphous silica content and large surface area. Appropriate furnace and the good grinding method is necessary for combustion and grinding RHA to obtain the excellent quality of ash.

\section{BURNING PROCESS OF RICE HUSK}

The rice husk is burn into ferrocement furnace or sometimes in boilers to produce RHA at controlled temperature. In furnace air ducts are provide which play two role, one is supply air to husk in combustion process and other is act as passages for fire. Air ducts are controlling commotion temperature. Electric fans are attached to air ducts which control the combustion temperature. Air ducts also reduce the carbon content in RHA, if there are no air ducts the carbon content will be more in ash and the strength of concrete will be low. In the burning process of RHA the temperature of boiler or furnace is around $700-800^{\circ} \mathrm{c}$ for 24 hours. After the 24 hours the temperature is about $52^{\circ} \mathrm{c}$. After the 48 hours the temperature of ash is about $25^{\circ} \mathrm{c}$. At $700-800^{\circ} \mathrm{c}$ temperate the silica is remain in amorphous silica, above this temperature the amorphous silica is converted into crystalline silica which is not useful in concrete. The air is providing into air ducts at the rate of velocity 12 meter per second. After burning the physical appearance of rice husk ash is shown in figure 4.1.

Figure 4.1 Rice husk ash

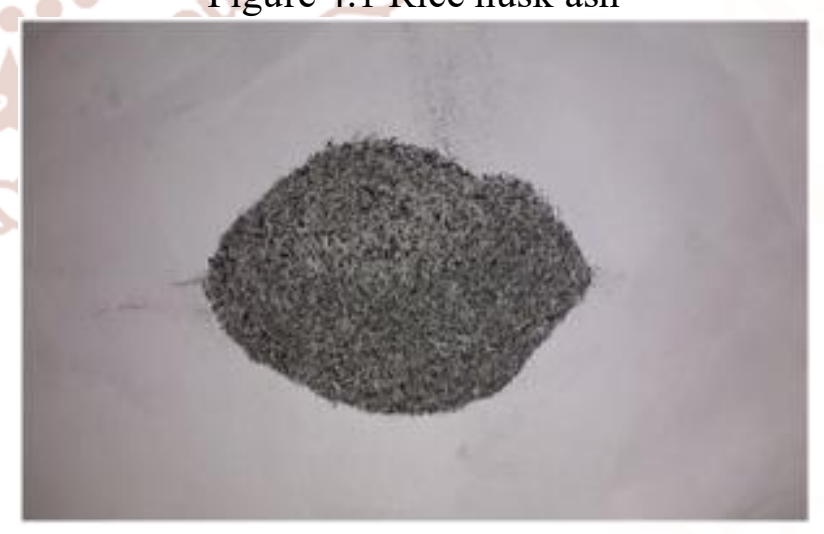

\section{GRINDING OF RICE HUSK ASH}

Grinding of burnt RHA was done into a Los Angeles machine. Specification and numbers of rods, as shown in Table 4.5, were tried for grinding burnt rice husk ash in this study. About $5.0 \mathrm{~kg}$ of ash was placed into the Los Angeles machine for every grinding. 
International Journal of Trend in Scientific Research and Development (IJTSRD) ISSN: 2456-6470

Table 4.5 Specification of Rod Used In Grinding Burnt Rice Husk

\begin{tabular}{|c|c|}
\hline \multicolumn{2}{|c|}{ SPECIFICATION OF RODS } \\
\hline NO. OF RODS & 20 \\
\hline LENGTH OF RODS & $450 \mathrm{MM}$ \\
\hline DIAMETER OF RODS & $20 \mathrm{MM}$ \\
\hline
\end{tabular}

\section{GRINDING PROCESS}

The grinding process should be done in proper manner in the loss angeles abrasion machine. The finer pozzolanic ash is superior. Fineness of rice husk ash is necessary because it influence the rate of reaction and the rate of gain in concrete strength.

Other than influence the rate of reaction, fineness also influences water-cement ratio, shrinkage, creep. The finer RHA particles yield larger surface area and increases strength of concrete. Chemically reactive very fine RHA would fill empty columns in concrete in an optimum manner. The particles of RHA retained on $45 \mathrm{~m}$ sieve should not be more than $12.0 \%$. Therefore, to get the required fineness, proper grinding of burnt ash is very important. In $90 \mathrm{~min}$ of grinding, fineness of $5 \mathrm{~kg}$ burnt husk obtained by combustion method met the standard requirements.
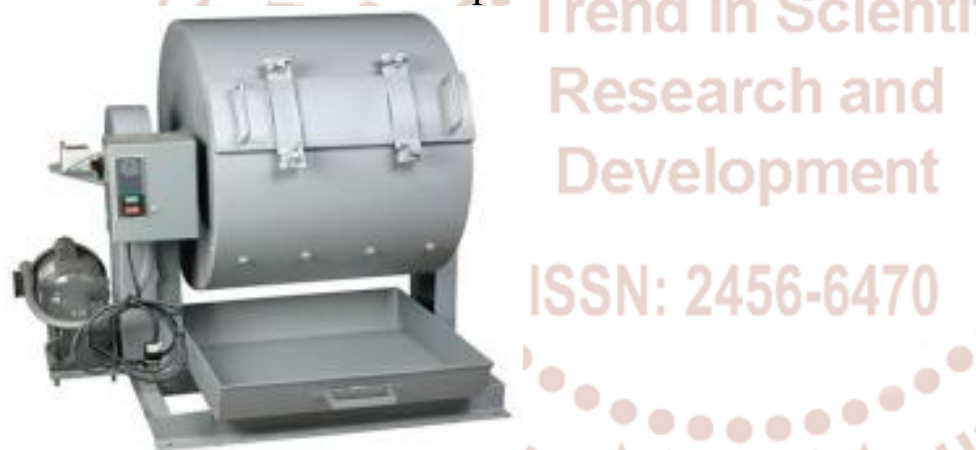

Figure 4.2 Los Angeles machine for grinding of RHA (Source-www.mltest.com)

Figure 4.3 shows that time required for grinding burnt ash

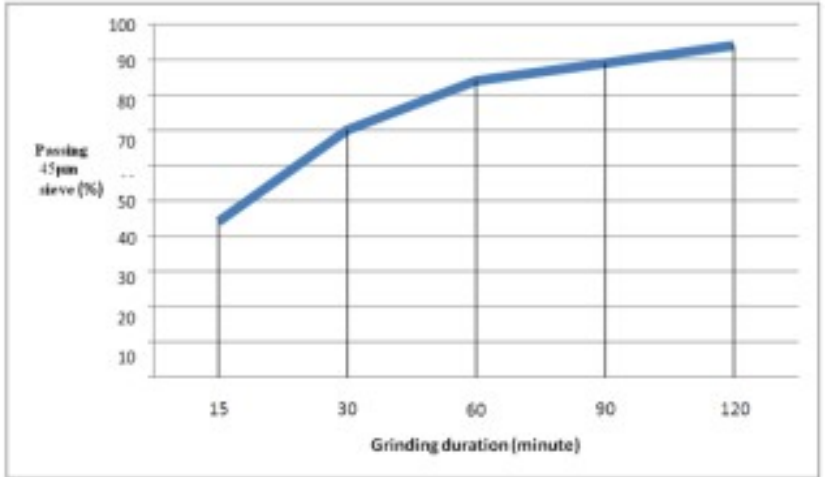

Variation of fineness with grinding duration for rice husk ash obtained

\section{MATERIAL PRODUCTION}

The production of RHA was obtained by burning the rice husk in a ferrocement furnace. Only ash that lies within the middle third of the furnace taken for grinding as it was considered as quality ash. Figure 4.4 show the sequence of operation in producing finely ground RHA for the present investigation. 


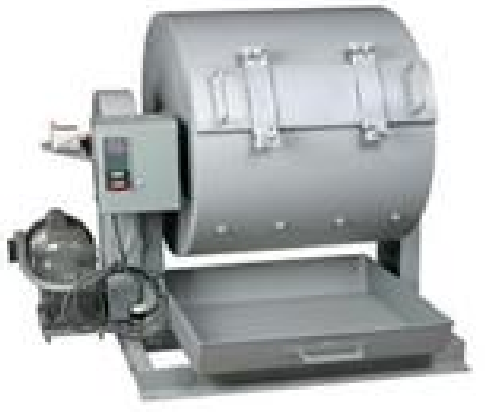

e). Los Angeles machine

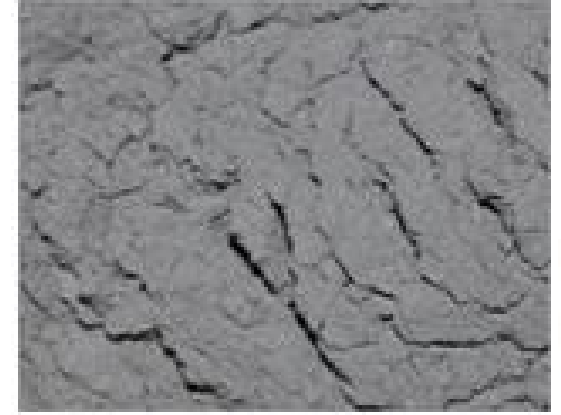

f). After grinding- RHA

Figure 4.4 Production of rice husk ash (Sourcehttp://en.wikipedia.org

GRADATION OFSAND (ASPERIS: 383-1970)

Weight of sample taken is $1500 \mathrm{~g}$.

Table 4.6 Sieve analysi

\begin{tabular}{|c|c|c|c|c|c|}
\hline Sieve size & $\begin{array}{l}\text { Weight } \\
\text { retained(gm) }\end{array}$ & $\begin{array}{c}\% \text { wt. } \\
\text { retained }\end{array}$ & $\begin{array}{c}\text { Cumulative } \% \\
\text { wt. retained }\end{array}$ & \%finer & Remarks \\
\hline $4.75 \mathrm{~mm}$ & 3 & 0.2 & 0.2 & 99.8 & \multirow{6}{*}{$\begin{array}{l}\text { Sand falls } \\
\text { in zone II }\end{array}$} \\
\hline $2.36 \mathrm{~mm}$ & 11 & 0.733 & 0.933 & 99.067 & \\
\hline $1.18 \mathrm{~mm}$ & 80.5 & 5.36 & 6.293 & 93.707 & \\
\hline $600 \mu$ & 747.5 & 49.8 & 56.09 & 43.91 & \\
\hline $300 \mu$ & 598 & 39.86 & 95.95 & 4.05 & \\
\hline $150 \mu$ & 50.5 & err 3.36 on & 99.31 & 0.69 & \\
\hline
\end{tabular}

As the percentage passing $600 \mu$ sieve is between 35 and 59 , the sand belongs to gradation zone II

\subsubsection{PARTICLESIZEDISTRIBUTION CURVE}

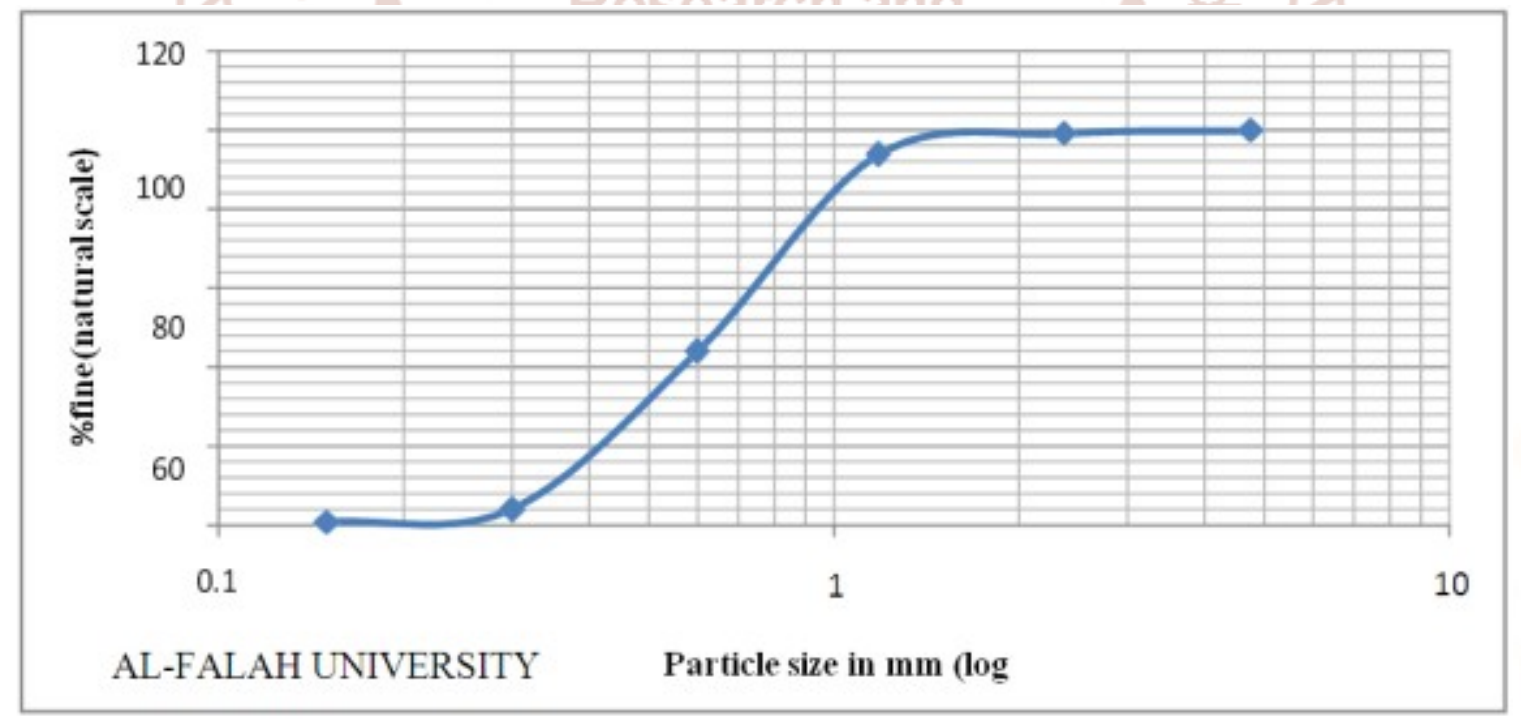

From the gradation curve we find $\mathrm{D} 10=0.33$

$\mathrm{Cc}=\mathrm{D} 302 /(\mathrm{D} 10 \times \mathrm{D} 60)=0.482 /(0.33 \times 0.72)=2.02$

Thus the sand is poorly graded sand.

\section{FINENESS MODULUS}

Fineness modulus is an empirical factor obtained by adding the cumulative percentages of aggregate retained on each of the standard sieves ranging from

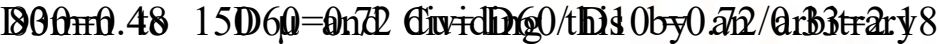
number 100.

Hence F.M. $=(0.2+0.933+6.293+56.09+$

$$
95.95+99.31) / 100=2.587
$$

As F.M. lies between 2.2 and 2.6 the sand is fine sand.

\section{SPECIFIC GRAVITY OF SAND}

The test is done by pycnometer method. The observations taken at $110 \mathrm{c}$ are as: Weight of empty 
pycnometer $\mathrm{W} 1=0.692 \mathrm{~kg}$ Weight of pycnometer + dry sample $\mathrm{W} 2=0.892 \mathrm{~kg}$ Weight of pycnometer + sample +water $\mathrm{W} 3=1.668 \mathrm{~kg}$ Weight of pycnometer + water W4 $=1.544 \mathrm{~kg}$ Specific gravity is given by the following formula:

$\mathrm{G}=(\mathrm{W} 2-\mathrm{W} 1) /\{(\mathrm{W} 2-\mathrm{W} 1)-(\mathrm{W} 3-\mathrm{W} 4)\}$

$\mathrm{G}=0.2 /(0.2-0.124)$

$\mathrm{G}=2.63$

\section{SPECIFIC GRAVITY OF COARSE AGGREGATE}

The test is conducted by wire basket method at $110 \mathrm{c}$ and the readings are presented as: Weight of oven dry sample $\mathrm{W} 1=500 \mathrm{~g}$

Weight of empty wire basket in water W2 $=891 \mathrm{~g}$ Weight of basket and sample in water W3 $=578.5 \mathrm{~g}$

Specific gravity $\mathrm{G}=\mathrm{W} 1 /\{\mathrm{W} 1-(\mathrm{W} 2-\mathrm{W} 3)\}$

$\mathrm{G}=500 /\{500-(891-578.5)\}$

$\mathrm{G}=2.67$

\section{STANDARD CONSISTENCY TEST FOR CEMENT}

Standard consistency of a cement paste is defined as the water content at which the paste will permit a vicat plunger having $10 \mathrm{~mm}$ dia and $50 \mathrm{~mm}$ length to penetrate to a depth of $33-35 \mathrm{~mm}$ from the top of the mould. The test is useful for finding out initial setting time, final setting time. The test is conducted using vicat's apparatus. The observations obtained during the test are as shown in Table4.7. Weight of cement taken for each trial is $400 \mathrm{~g}$.

Table 4.7 Normal consistency of cement

\begin{tabular}{|c|c|c|}
\hline Trial no. & $\begin{array}{c}\text { Water } \\
\text { content }(\%)\end{array}$ & $\begin{array}{c}\text { Penetration( } \mathbf{m m} \\
\text { ) }\end{array}$ \\
\hline 1 & 25 & 15 \\
\hline 2 & 27 & 20 \\
\hline 3 & 29 & 32 \\
\hline 4 & 30 & 34 \\
\hline 5 & 31 & 35.5 \\
\hline
\end{tabular}

The standard consistency of the cement is obtained as $30 \%$

\section{INITIAL SETTING TIME OF CEMENT}

Initial setting time of cement is regarded as the time elapsed between the moments that the water is added to the cement, to the time that the paste starts losing its plasticity.

In vicat"s apparatus, it is measured as the period elapsed between the time when water is added to the cement and the time at which the needle penetrates the test block to a depth equal to $33-35 \mathrm{~mm}$ from the top at water content of 0.85 times the standard consistency. The observations obtained at a temperature of $80 \mathrm{c}$ are as: Weight of cement $=400 \mathrm{~g}$ Weight of water $=0.85 \times 30 / 100 \times 400=102 \mathrm{~g}$. Time at which water is added to the cement 2:05 pm Time at which needle penetrates to a depth of $33-35 \mathrm{~mm}$ 5:45 pm. Initial setting time is obtained as $3 \mathrm{hr} 40$ $\min$.

\section{FINAL SETTING TIME OF CEMENT}

The final setting time is the time elapsed between the moment the water is added to the cement, and the time when the paste has completely lost its plasticity and has attained sufficient firmness to resist certain definite pressure. In vicat ${ }^{\mathrm{ee}} \mathrm{s}$ apparatus, cement is considered finally set, when, upon, lowering the attachment gently cover the surface of the test block, the centre needle makes an impression, while the circular cutting edge of the attachment fails to do so, that is the needle does not pierce more than $0.5 \mathrm{~mm}$. The observations obtained are as:

Time at which water is added to the cement 2:05 pm Time at which the circular edge fail to make an impression 7:25 pm Final setting time is obtained as 5 hr $20 \mathrm{~min}$.

\subsection{TRIAL MIX DESIGN}

A trial mix has been designed for an assumed compaction factor of 0.80 as per IS $10262-1982$ for M40 grade. The trial mix is obtained as 1:0.865:2.59 for water cement ratio of 0.40 .

\subsubsection{COMPACTION FACTOR}

Compaction factor is defined as the ratio of density achieved when concrete is allowed to fall through a standard height and the density of the same concrete fully compacted. The observations obtained during the test are: Weight of empty cylinder $\mathrm{W} 1=14 \mathrm{~kg}$.

Weight of cylinder + partially compacted concrete $\mathrm{W} 2=24.6 \mathrm{~kg}$. Weight of cylinder + fully compacted concrete $\mathrm{W} 3=27.5 \mathrm{~kg}$.

C.F. $=(\mathrm{W} 2-\mathrm{W} 1) /(\mathrm{W} 3-\mathrm{W} 1)$

C.F. $=(24.6-14) /(27.5-14)$

C.F. $=0.785$

\section{DESIGN MIX: IS 10262-1982}

FOR M40 GRADE OF CONCRETE

Characteristic strength required at 28 days $=40$ Mpa. 
International Journal of Trend in Scientific Research and Development (IJTSRD) ISSN: 2456-6470

$>$ Target mean strength $=$ fck $+1.65 \times \mathrm{S}$

$=40+1.65 \times 5.6$

$=49.24 \mathrm{Mpa}$.

$>$ The $\mathrm{w} / \mathrm{c}$ ratio is obtained as 0.40 from the IS 4562000.

$>$ For $20 \mathrm{~mm}$ maximum size aggregate, sand conforming to grading zone II, w/c ratio of 0.35 and C.F. of 0.8 , water content per cubic meter of concrete $=180 \mathrm{~kg}$ and sand content as percentage of total aggregate by absolute volume $=25 \%$.

$>$ Adjustments to water and sand content.

- For C.F. of 0.785 no adjustment to water and no adjustment to sand.

- Actually we have to take mixing water as 180 litres/m3 as per IS 10262-1982 but If the saturation point of the super plasticizer is known, it is suggested that a water content of 153 litres / m3.

- For w/c ratio of 0.40 sand is adjusted by increment of $1 \%$ as $(25+1)$

$=26 \%$ of total aggregate and no adjustment is made for sand.

- Final water content $=153 \mathrm{~kg} / \mathrm{m} 3$ and sand content of $26 \%$ of total aggregate.
$>$ Cement content $=153 / 0.40=382.5 \mathrm{~kg}$.

$>$ Entrapped air for maximum size of aggregate $=2 \%$.

Aggregate content is obtained by using the formula.

Table 4.8 Mix proportion of M40 grade of concrete

\begin{tabular}{|c|c|c|c|c|}
\hline $\begin{array}{c}\text { Grade of } \\
\text { Concrete }\end{array}$ & $\begin{array}{c}\text { Water } \\
(\mathrm{Kg})\end{array}$ & $\begin{array}{c}\text { Cemen } \\
\mathrm{t}(\mathrm{Kg})\end{array}$ & $\begin{array}{c}\text { Fineaggre } \\
\text { Gate}(\mathrm{Kg})\end{array}$ & $\begin{array}{c}\text { Coarceag } \\
\text { Gregate } \\
(\mathrm{K} \mathrm{G})\end{array}$ \\
\hline INCUM & 153 & 382.5 & 482.46 & 1394.06 \\
\hline M40 & 0.40 & 1 & 1.261 & 3.64 \\
\hline
\end{tabular}

4.17 MIX PROPORTIONING OF RICE HUSK ASH (RHA) CONCRETE

In this method, five replacements of cement i.e., 5\%, $7.5 \%, 10 \%, 12.5 \%$ and $15 \%$ with Rice husk ash (RHA) are done, whereas the total binder content remains the same. The mix proportions considered for each replacement by replacement method by RHA are presented in tables.

Table 4.8 Mix proportions of rice husk ash concrete for $5 \%$ replacement of cement

\begin{tabular}{|c|c|c|c|c|c|c|}
\hline GRADEOF & CEMENT & RICEH & FINEAGGRE & COARSEAGG & WATER & SUPER \\
\hline CONCRETE & $\begin{array}{l}\text { IN } \\
\text { KGS }\end{array}$ & $\begin{array}{c}\text { USK } \\
\text { ASHIN } \\
\text { KGS }\end{array}$ & GATEIN KGS & REGATEIN KGS & $\begin{array}{l}\text { IN } \\
\text { LTRS }\end{array}$ & $\begin{array}{c}\text { PLASTICIZER } \\
\text { IN } \\
\text { LTRS }\end{array}$ \\
\hline M40 & 0.95 & 0.05 & 1.261 & 3.64 & 0.40 & 1 \\
\hline INCUM & 363.37 & 19.125 & 482.46 & 1394.06 & 153 & 3.63 \\
\hline
\end{tabular}

Table 4.9 Mix proportions of rice husk ash concrete for $7.5 \%$ replacement of cement MIX PROPORTIONS OF RICE HUSK ASH CONCRETE FOR7.5\% REPLACEMIENT

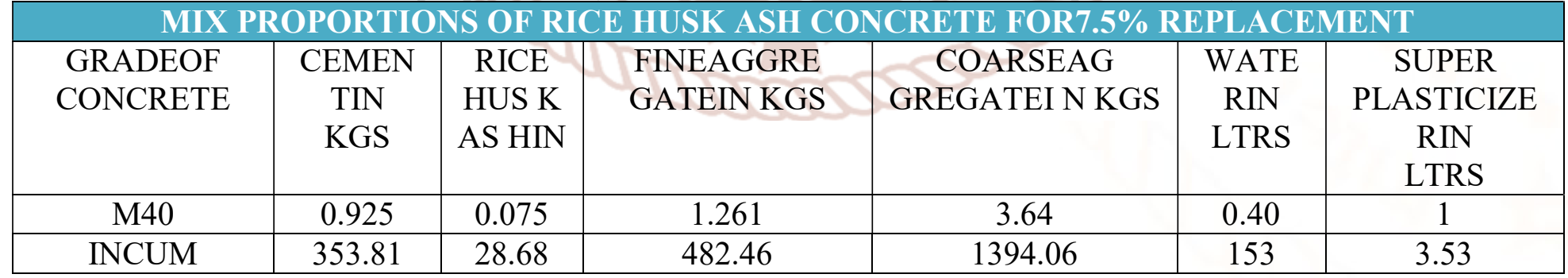

Table 4.10 Mix proportions of rice husk ash concrete for $10 \%$ replacement of cemen

\begin{tabular}{|c|c|c|c|c|c|c|}
\hline \multicolumn{2}{|c|}{ MIX PROPORTIONS OF RICE HUSK ASH CONCRETE FOR10\% REPLACEMINT } \\
\hline GRADEOF & CEMENT & RICE & FINEAGGRE & COARSEAGG & WATER & SUPER \\
CONCRETE & IN & HUSK & GATEIN KGS & REGATEIN KGS & IN \\
KGS & $\begin{array}{c}\text { ASH } \\
\text { INK GS }\end{array}$ & & & & PLASTICIZER \\
IN \\
LTRS
\end{tabular}


International Journal of Trend in Scientific Research and Development (IJTSRD) ISSN: 2456-6470

Table 4.11 Mix proportions of rice husk ash concrete for $12.5 \%$ replacement of cement

\begin{tabular}{|c|c|c|c|c|c|c|}
\hline \multicolumn{6}{|c|}{ MIX PROPORTIONS OF RICE HUSK ASH CONCRETE FOR12.5\% REPLACEMIENT } \\
\hline GRADEOF & $\begin{array}{c}\text { CEMENT } \\
\text { IN } \\
\text { KGS }\end{array}$ & $\begin{array}{c}\text { RICE } \\
\text { HUSK } \\
\text { ASH } \\
\text { INK GS }\end{array}$ & $\begin{array}{c}\text { FINEAGGRE } \\
\text { GATEIN KGS }\end{array}$ & $\begin{array}{c}\text { COARSEAGG } \\
\text { REGATEIN KGS }\end{array}$ & $\begin{array}{c}\text { WATER } \\
\text { IN } \\
\text { LTRS }\end{array}$ & $\begin{array}{c}\text { SUPER } \\
\text { PLASTICIZER } \\
\text { IN } \\
\text { LTRS }\end{array}$ \\
\hline M40 & 0.875 & 0.125 & 1.261 & 3.64 & 0.40 & 1 \\
\hline INCUM & 334.68 & 47.81 & 482.46 & 1394.06 & 153 & 3.34 \\
\hline
\end{tabular}

Table 4.12 Mix proportions of rice husk ash concrete for $15 \%$ replacement of cement

\begin{tabular}{|c|c|c|c|c|c|c|}
\hline \multicolumn{7}{|c|}{ MIX PROPORTIONS OF RICE HUSK ASH CONCRETE FOR 15\% REPLACEMIENT } \\
\hline $\begin{array}{l}\text { GRADEOF } \\
\text { CONCRETE }\end{array}$ & $\begin{array}{c}\text { CEMENT } \\
\text { IN } \\
\text { KGS }\end{array}$ & $\begin{array}{c}\text { RICE } \\
\text { HUSK } \\
\text { ASH } \\
\text { INK GS }\end{array}$ & $\begin{array}{l}\text { FINEAGGRE } \\
\text { GATEIN KGS }\end{array}$ & $\begin{array}{c}\text { COARSEAGG } \\
\text { REGATEIN KGS }\end{array}$ & $\begin{array}{c}\text { WATER } \\
\text { IN } \\
\text { LTRS }\end{array}$ & $\begin{array}{c}\text { SUPER } \\
\text { PLASTICIZER } \\
\text { IN } \\
\text { LTRS }\end{array}$ \\
\hline M40 & 0.85 & 0.15 & 1.261 & 3.64 & 0.40 & 1 \\
\hline INCUM & 325.125 & 57.37 & 11482.46 & 47/7/ 1394.06 & 153 & 3.25 \\
\hline
\end{tabular}

4.17.1 MIXTURE PROPORTIONS OF RICE HUSK CONCRETE INVESTIGATED

\begin{tabular}{|c|c|c|c|c|c|c|}
\hline Mixture & $\begin{array}{l}\text { Cement } \\
\text { (kg/ } \\
\text { m3) }\end{array}$ & $\begin{array}{c}\text { RHA } \\
(\mathrm{kg} / \mathrm{m} 3)\end{array}$ & $\begin{array}{l}\text { Water } \\
(\mathrm{kg} / \mathrm{m} 3)\end{array}$ & $\begin{array}{l}\text { Fine aggregate } \\
\qquad \begin{array}{l}(\mathrm{kg} / \\
\mathrm{m} 3)\end{array}\end{array}$ & $\begin{array}{c}\text { Coarse } \\
\text { aggregate } \\
(\mathrm{kg} / \mathrm{m} 3) \\
\end{array}$ & $\begin{array}{c}\text { SP } \\
\text { (1\% by the weight of } \\
\text { cement) }\end{array}$ \\
\hline $0 \%$ & 382.5 & 0 & 153 กล & On 482.46 ull & al 1394.06 & 3.82 \\
\hline $5 \%$ RHA & 363.37 & 19.125 & 153 & 482.46 & 1394.06 & 3.63 \\
\hline $7.5 \%$ RHA & 353.81 & 28.68 & 153 & 482.46 & 1394.06 & 3.53 \\
\hline $10 \%$ RHA & 344.25 & 38.25 & $153 \mathrm{es}$ & ar 482.46 d & 1394.06 & 3.44 \\
\hline $\begin{array}{c}12.5 \% \\
\text { RHA } \\
\end{array}$ & 334.68 & 47.81 & 153 & $\begin{array}{c}482.46 \\
\text { lophent }\end{array}$ & 1394.06 & 3.34 \\
\hline $15 \%$ RHA & 325.125 & 57.37 & 153 & 482.46 & 1394.06 & 3.25 \\
\hline
\end{tabular}

CASTING OF TEST SPECIMENS: (AS PER IS:

\section{6-1959)}

\section{PREPARATION OF MATERIALS}

All materials shall be brought to room temperature, preferably $27 \pm 3^{\circ} \mathrm{C}$ before start the results. The cement samples, on arrival at the laboratory, shall be carefully mixed dry either by hand or in an appropriate mixer in such a manner as to ensure the maximum possible blending and uniformity in the material, care is being taken. The cement shall then be stored in a dry place, preferably in air-tight metal containers. Samples of aggregates for each batch of concrete shall be of the desired grading and shall be in an air-dried condition. In general, the aggregate shall be separated into fine and coarse portion and recombined for each concrete batch in such a way as to produce the desired grading. IS sieve 480 shall be normally used for separating the fine and coarse fractions, but where special grading are being investigated, both fine and coarse aggregate shall be separated into different sizes.

\section{PROPORTIONING}

The proportions of the materials, including water, in concrete mixes used for determining the suitability of the materials available, shall be similar in all respects to those to be employed in the work. Where the proportions of the ingredients of the concrete as used on the site are to be specified by volume, they shall be calculated from the proportions by weight used in the test cubes and the unit weights of the materials.

\section{WEIGHING}

Weigh batching is the correct method of measuring the materials. For important concrete, invariably weigh batching should be adopted. Use of weight system in batching, facilitates accuracy, flexibility and simplicity.

\section{MIXING CONCRETE}

Thorough mixing of the materials is essential for the production of uniform concrete. The mixing should 
ensure that the mass become homogeneous, uniform in colour and consistency. There are two methods adopting for mixing concrete one is hand mixing and other is machine mixing. In this study the mixing of materials is done by hand.

\section{COMPACTION OF TEST SPECIMENS: PER IS: 516-1959)}

Compaction of concrete is the process adopted for expelling the entrapped air from the concrete. In the process of mixing, transporting and placing of concrete air is likely to get entrapped in the concrete. The lower the workability, higher is the amount of air entrapped. In other words, stiff concrete mix has high percentage of entrapped air and, therefore, would need higher compacting efforts than high workable mixes. Therefore, it is imperative that $100 \%$ compacting of concrete is one of the most important aim to be kept in mind in good concrete making practices.

\section{COMPACTION BY VIBRATION}

When compacting by vibration, each layer shall be vibrated by means of an electric or vibrator or by means of a suitable vibrating table until the specified condition is attained.

\section{PLACING MOULDS ON THE VIBRATING TABLE}

This is the special case of formwork vibrator, where the vibrator is clamped to the table or table is mounted on springs which are vibrated transferring the vibration to the table. They are commonly used for vibrating concrete cubes. Any specimen kept on the table gets vibrated. This idea adopted mostly in laboratory and in the making small but precise prefabricated R.C.C members. The vibrating table is shown in figure 4.6.

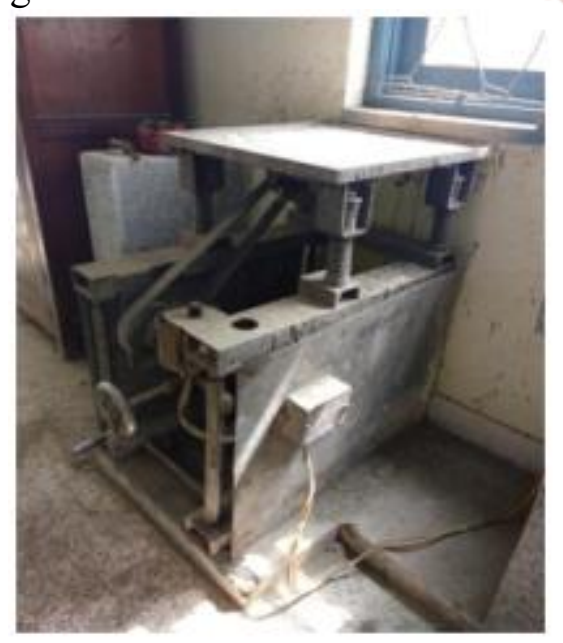

Figure 4.6 Vibrating table

\section{CURING OF TEST SPECIMENS: (AS PER IS: 516-1959)}

The test specimens shall be stored on the site at a place free from vibration, under damp matting, sacks or other similar material for 24 hours $+1 / 2$ hour from the time of adding the water to the other ingredients.

The temperature of the place of storage shall be within the range of 22 to $32^{\circ} \mathrm{C}$. After the period of 24 hours, they shall be marked for later classification, removed from the moulds and, unless required for testing within 24 hours, stored in clean water at a temperature of 24 to $30^{\circ} \mathrm{C}$ until they are transported to the testing laboratory. They shall be sent to the testing laboratory well packed in damp sand, damp sacks, or other suitable material so as to arrive there in a damp condition not less than 24 hours before the time of test. On arrival at the testing laboratory, the specimens shall be stored in water at a temperature of $27 \pm 2^{\circ} \mathrm{C}$ until the time of test. Curing of test specimens are shown in figure 4.7.

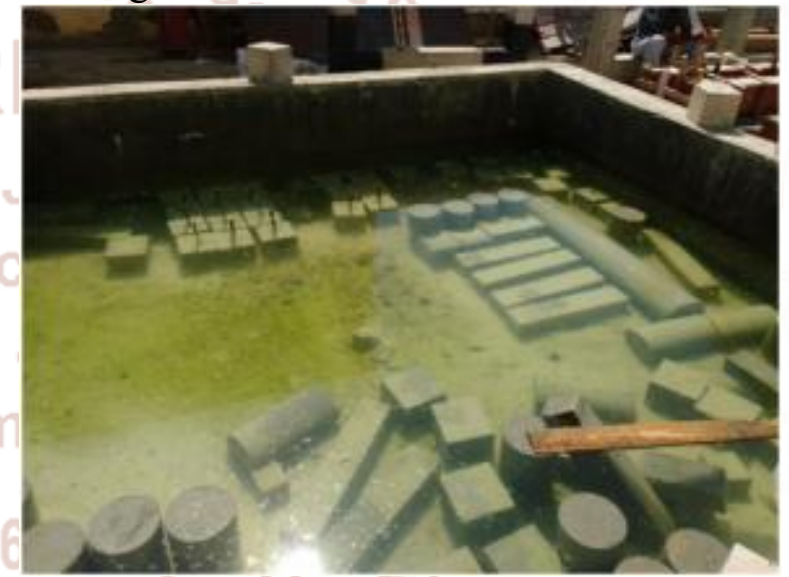

Figure 4.7 Curing of specimens

\section{TESTS AND RESULTS}

The details of experimental investigations carried out on the test specimens to study the strength-related properties of concrete using Rice husk ash. The strength- related properties such as compressive strength, splitting tensile strength, and flexural strength were studied.

\section{TESTS}

\section{CUBE COMPRESSIVE STRENGTH}

For cube compression testing of concrete, $150 \mathrm{~mm}$ cubes were used. All the cubes were tested in saturated condition, after wiping out the surface moisture. The tests were carried out after the specimen has been centered in the testing machine.

Loading was continued till the specimen fails and reading note down from the automatic universal 
testing machine. The ultimate load divided by the cross sectional area of the specimen is equal to the ultimate cube compressive strength. The load on the specimen is shown in Figure 5.1. Pattern of typical compressive failure mode shape of cube specimen is shown in Figure 5.2.

$\mathbf{f c}=\mathbf{L} / \mathbf{A}$

Where,

$\mathrm{fc}=$ compressive strength in $\mathrm{Mpa} \mathrm{L}=$ load in Newton $\mathrm{A}=$ area of the specimen in $\mathrm{mm}$

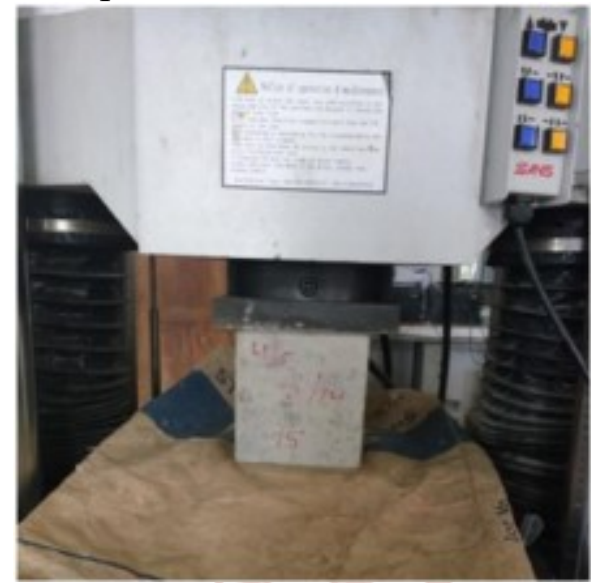

Figure 5.1 Compressive strength of cube test in universal testing machine

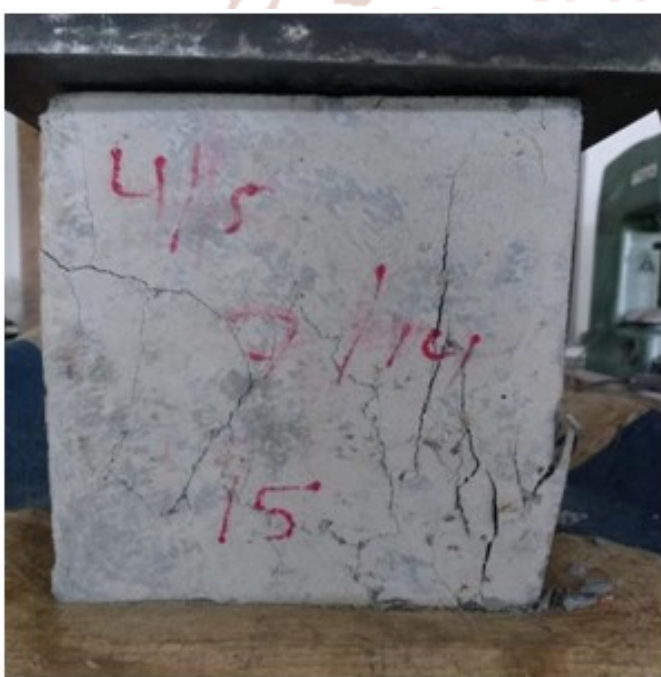

Figure 5.2 Failure of specimen

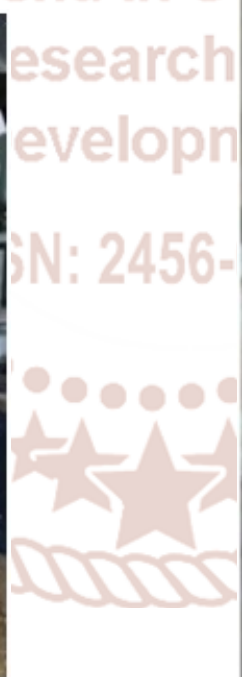

\section{SPLITTING TENSILE STRENGTH}

This is an indirect test to determine the tensile strength of cylindrical specimens. Splitting tensile strength tests were carried out on cylinder specimens of size $150 \mathrm{~mm}$ diameter and $300 \mathrm{~mm}$ length. To avoid the direct load on the specimen the cylindrical specimens were kept below the iron plates .The load was applied gradually till the specimens split and readings were noted. The test set up for the splitting tensile strength on the cylinder specimen, with the iron plates to avoid the direct load on the specimen is shown in Figure 5.3. Pattern of typical splitting tensile failure mode shapes of cylinder specimen is shown in Figure 5.4. The splitting tensile strength has been calculated using the following formula:

\section{$\mathrm{ft}=\mathbf{2 P} / \boldsymbol{\pi} \mathrm{DL}$}

Where $\mathrm{ft}=$ splitting tensile strength of the specimen in $\mathrm{MPa} \mathrm{P}=$ maximum load in $\mathrm{N}$ applied to the specimen $\mathrm{D}=$ measured diameter of the specimen in $\mathrm{mm}$, and $\mathrm{L}$ $=$ measured length of the specimen in $\mathrm{mm}$.

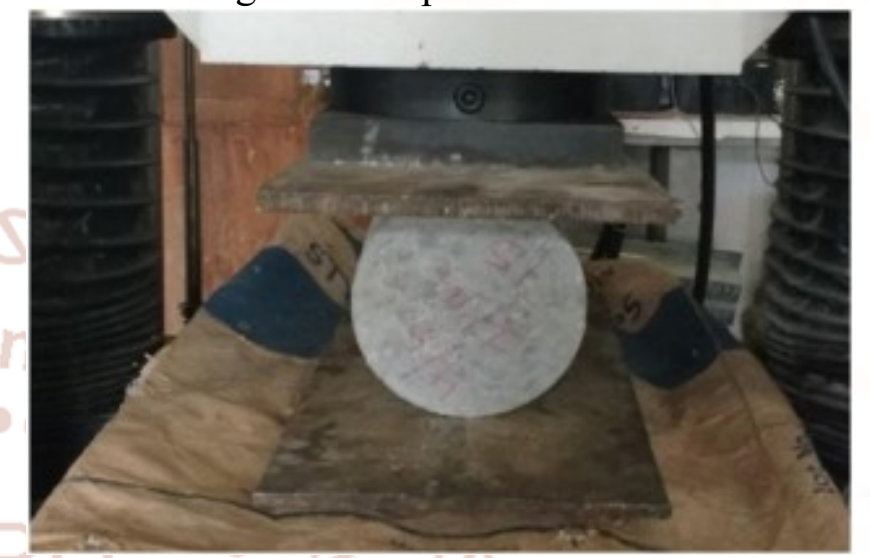

Figure 5.3 Splitting tensile strength of the cylindrical specimen in universal testing machine

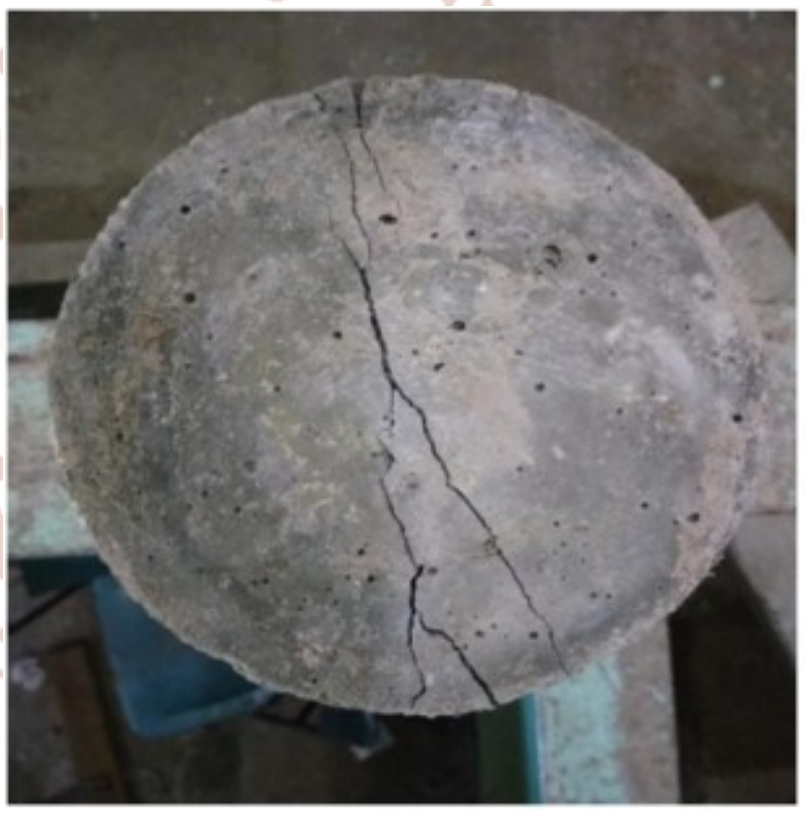

Figure 5.4 Failure of specimen

\section{FLEXURAL STRENGTH}

Flexural strength tests were carried out on $100 \mathrm{~mm} x$ $100 \mathrm{~mm} \times 500 \mathrm{~mm}$ beam by subjecting the specimen to two-point loading to determine the flexural strength. The test set up for the flexural strength on the beam specimen with the necessary settings is shown in Figure 5.5. Pattern of typical flexural failure mode shape of beam specimen is shown in Figure 5.6. 
The flexural strength or modulus of rupture has been calculated using the following formula:

fr $=$ PL/BD2

Where $\mathrm{fr}=$ flexural tensile strength of the specimen in $\mathrm{MPa} \mathrm{P}=$ maximum load in $\mathrm{N}$ applied to the specimen $\mathrm{L}=$ length in $\mathrm{mm}$ of the span on which the specimen was supported $\mathrm{B}=$ measured width of the specimen in $\mathrm{mm}$, and

$\mathrm{D}=$ measured depth of the specimen in $\mathrm{mm}$ at the point of failure

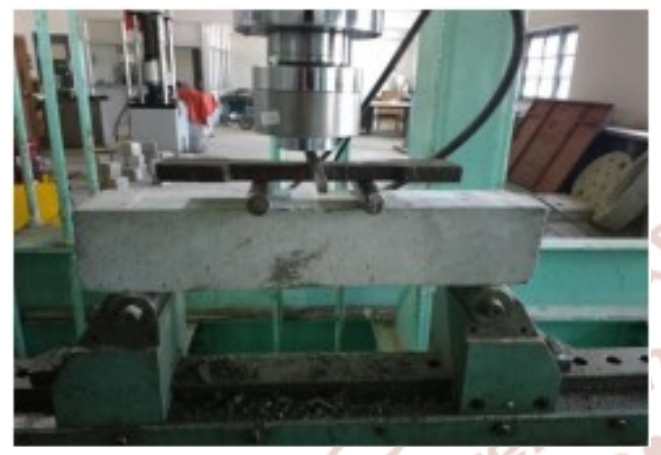

Figure 5.5 Flexural strength of the beam in testing machine

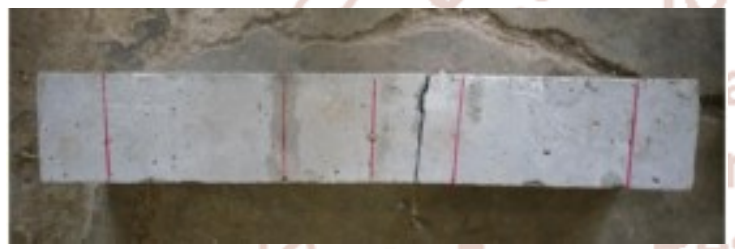

Figure 5.6 Failure of specimen

\subsection{RESULTS AND DISCUSSION}

\subsubsection{CUBE COMPRESSIVE STRENGTH}

The cube compressive strength results at the various ages such as 7, 28 days and at the replacement levels such as $0 \%, 5 \%, 7.5 \%, 10 \%, 12.5 \%$ and $15 \%$ of rice husk ash are presented in Table 5.1. The variations of compressive strength at 7 and 28 days with different percentage of RHA were plotted in the form of graphs as shown in Figures 5.7 and 5.8.

Table 5.1 Compressive strength results of different age and different replacement level

\begin{tabular}{|c|c|c|}
\hline $\begin{array}{c}\text { RICEHUSKASH } \\
(\%)\end{array}$ & $\begin{array}{c}\text { 7days } \\
\text { (Mpa) }\end{array}$ & $\begin{array}{c}\text { 28days } \\
\text { (Mpa) }\end{array}$ \\
\hline 0 & 29.32 & 41.91 \\
\hline 5 & 27.58 & 43.76 \\
\hline 7.5 & 27.89 & 46.18 \\
\hline 10 & 26.90 & 44.82 \\
\hline 12.5 & 26.20 & 42.18 \\
\hline 15 & 23.21 & 39.14 \\
\hline
\end{tabular}

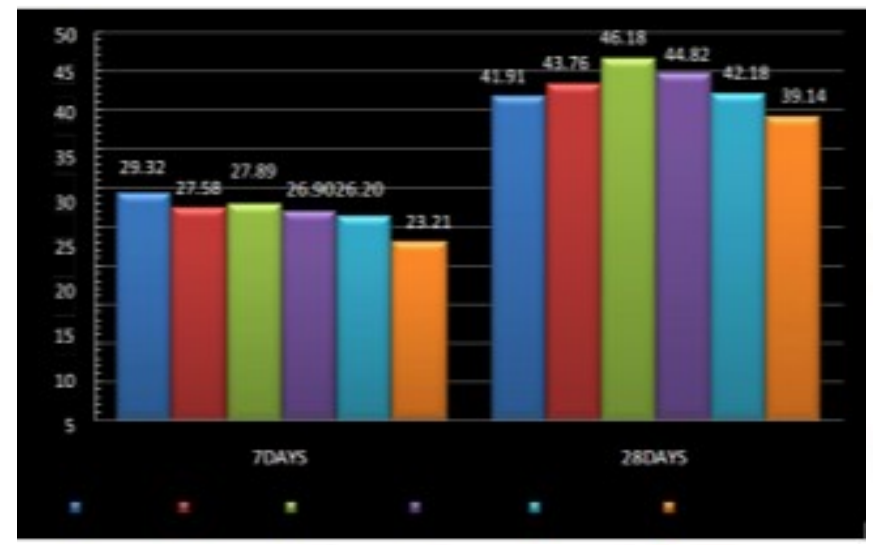

Figure5.7 Influence of RHA on compressive strength

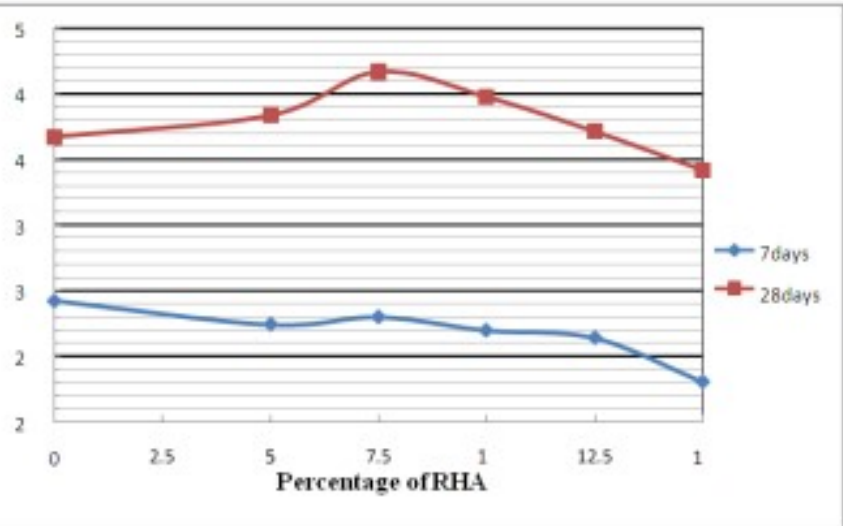

Figure 5.8 Graph on influence of RHA on compressive strength

From the test results it was observed that the maximum compressive strength is obtained for mixes with $7.5 \%$ RHA at age 28 days. For water-cement ratios at 28 days age the optimum replacement level of cement by RHA is $7.5 \%$. At the age of 7 days of concrete the compressive strength of concrete is decrease and the maximum strength of concrete at 7 days is with $0 \%$ replacement of cement by RHA in concrete. where RHA content is exactly what is required for reacting with the calcium hydroxide present. This may be the reason as more and dense C$\mathrm{S}-\mathrm{H}$ gel acts as an impervious layer which prevents the water to enter through it and thereby arrests further hydration. Therefore excess RHA added beyond this limit decreases the strength of concrete.

\section{SPLITTING TENSILE STRENGTH}

The Splitting Tensile strength results at the various ages such as 7,28 days and at the replacement levels such as $0 \%, 5 \%, 7.5 \%, 10 \%, 12.5 \%$ and $15 \%$ of rice husk ash are presented in Table 5.4. The variations of splitting tensile strength at 7 and 28 days with different percentage of RHA were plotted in the form of graphs as shown in Figures 5.9 and 5.10. 
International Journal of Trend in Scientific Research and Development (IJTSRD) ISSN: 2456-6470

\begin{tabular}{|c|c|c|}
\hline $\begin{array}{c}\text { RICEHUSKASH } \\
(\%)\end{array}$ & $\begin{array}{c}\text { 7days } \\
\text { (Mpa) }\end{array}$ & $\begin{array}{c}\text { 28days } \\
\text { (Mpa) }\end{array}$ \\
\hline 0 & 2.22 & 3.128 \\
\hline 5 & 1.90 & 3.118 \\
\hline 7.5 & 2.092 & 3.316 \\
\hline 10 & 1.90 & 3.28 \\
\hline 12.5 & 1.89 & 3.075 \\
\hline 15 & 1.650 & 2.911 \\
\hline
\end{tabular}

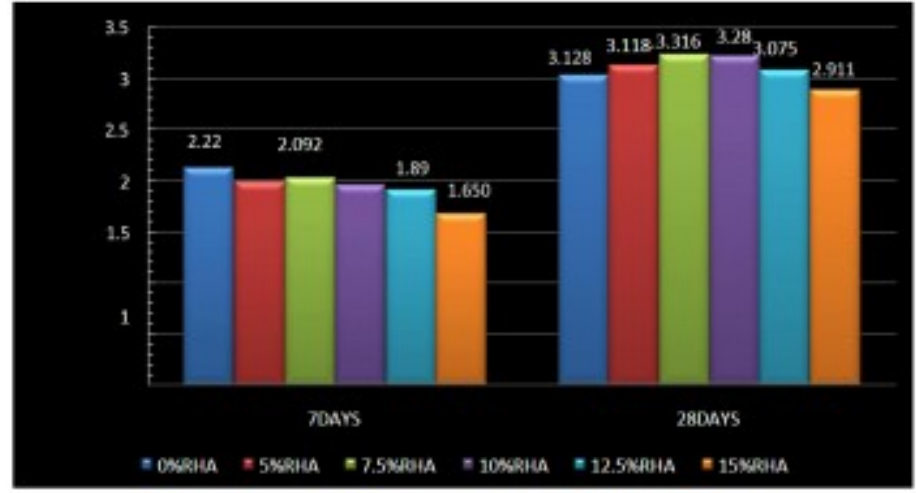

Figure 5.9 Influence of RHA on split tensile strength

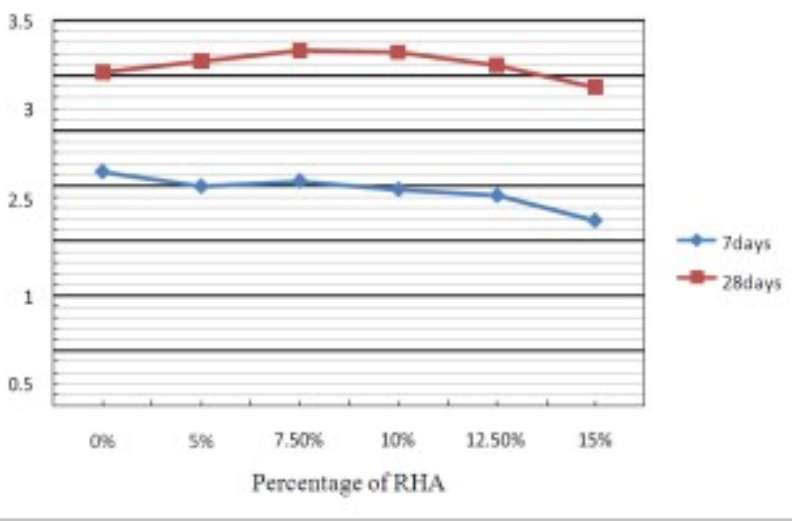

Figure 5.10 Graph on influence of RHA on split tensile strength

From the test results, it was observed that the maximum splitting tensile strength was obtained for mix with $7.5 \%$ replacement of cement by RHA at 28 days. It was also observed that the splitting tensile strength increases with the increase in RHA content up to $7.5 \%$ beyond that the strength decreases. At the age of 7 days of concrete the split tensile strength of concrete is decrease and the maximum split tensile strength of concrete at 7 days is without replacement of cement by RHA in concrete.

\section{FLEXURAL STRENGTH}

The Flexural strength results at the various ages such as 7,28 days and at the replacement levels such as $0 \%$, $5 \%, 7.5 \%, 10 \%, 12.5 \%$ and $15 \%$ of rice husk ash are presented in Table 5.7. The variations in flexural strength at the age of 7 days and 28 days with different percentage of RHA were plotted in Figures 5.11 and 5.12. The variations of Flexural tensile strength at 7 and 28 days with different percentage of RHA were plotted in the form of graphs as shown in Figures 5.11 and 5.12.

\begin{tabular}{|c|c|c|}
\hline $\begin{array}{c}\text { RICEHUSKASH } \\
(\%)\end{array}$ & $\begin{array}{c}\text { 7days } \\
\text { (Mpa) }\end{array}$ & $\begin{array}{c}\text { 28days } \\
\text { (Mpa) }\end{array}$ \\
\hline & 3.94 & 5.31 \\
\hline 5 & 3.49 & 5.60 \\
\hline 7.5 & 3.81 & 5.69 \\
\hline 10 & 3.41 & 5.58 \\
\hline 12.5 & 3.36 & 5.60 \\
\hline 15 & 3.19 & 5.09 \\
\hline
\end{tabular}

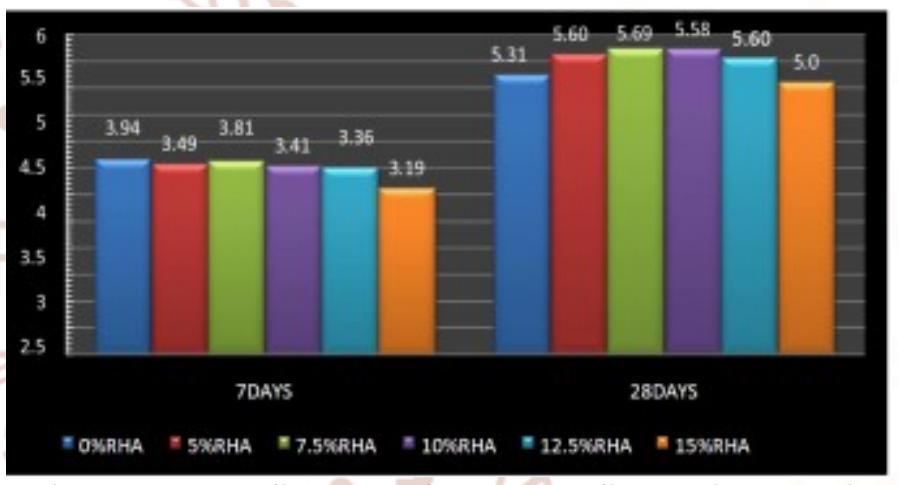

Figure 5.11 Influence of RHA on flexural strength

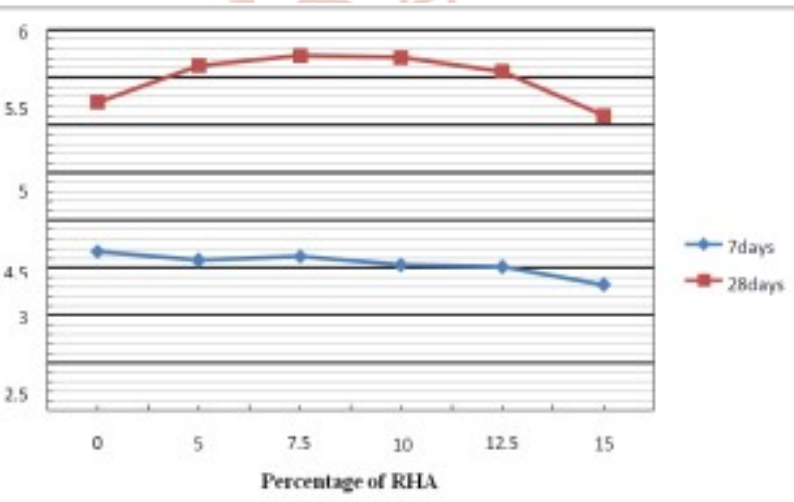

Figure 5.12 Graph on influence of RHA on Flexural strength

From the test results, it was observed that the maximum flexural strength was obtained for concrete mix with $7.5 \%$ replacement of cement by RHA at 28 days. It was also observed that the splitting tensile strength increases with the increase in RHA content up to $7.5 \%$ beyond that the strength decreases. At the age of 7 days of concrete the split tensile strength of concrete is decrease and the maximum split tensile strength of concrete at 7 days is without replacement of cement by RHA in concrete. 


\section{SETTING TIMES}

The initial setting time and the final setting times are at the various replacement levels such as $0 \%, 5 \%$, $7.5 \%, 10 \%, 12.5 \%$ and $15 \%$ of rice husk ash are presented in Table 5.12. The test from OPC paste has done in winter so the initial and final setting time is more than other pastes containing different percentage of replacement of cement by RHA. The initial and final setting time is increasing from 5\%-12.5\% replacement level of cement by RHA but the initial and final setting time is decreasing at $15 \%$ replacement level of cement by RHA.

\begin{tabular}{|c|c|c|c|}
\hline Paste & $\begin{array}{c}\text { Normal } \\
\text { consistency } \\
\%\end{array}$ & $\begin{array}{c}\text { Initial } \\
\text { setting } \\
\text { time min }\end{array}$ & $\begin{array}{c}\text { Final } \\
\text { setting } \\
\text { time min }\end{array}$ \\
\hline OPC & 30 & 180 & 280 \\
\hline $5 \%$ of RHA & 27 & 95 & 180 \\
\hline $7.5 \%$ of RHA & 30 & 125 & 180 \\
\hline $10 \%$ of RHA & 33 & 120 & 250 \\
\hline $\begin{array}{c}12.5 \% \text { of } \\
\text { RHA }\end{array}$ & 35 & 140 & 245 \\
\hline $15 \%$ of RHA & 32.5 & 95 & 200 \\
\hline
\end{tabular}

Figure 5.13 Vicat apparatus for testing of setting times of paste

\section{COST ANALYSIS FOR 1 M3 OF CONCRETE}

\begin{tabular}{|c|c|c|c|c|c|}
\multicolumn{7}{c|}{ Table 5.2 WITHOUT RHA } \\
\cline { 1 - 4 } & CEMIENT & $\begin{array}{c}\text { FINEAG } \\
\text { GREGATE }\end{array}$ & $\begin{array}{c}\text { COARSEA } \\
\text { GGREGATE }\end{array}$ & $\begin{array}{c}\text { S.P } \\
(\mathbf{1} \%)\end{array}$ & $\begin{array}{c}\text { TOTAL } \\
\text { PRICE }\end{array}$ \\
\hline QUANTITY & 382.5 & 482.46 & 1394.06 & 3.82 & 5783.47 \\
\cline { 1 - 2 } PRICE RS. & 3313 & 596.87 & 1720.40 & 152.2 & INRRUP EES \\
\hline
\end{tabular}

Table 5.3 WITH RHA

\begin{tabular}{|c|c|c|c|c|c|c|}
\hline & $\begin{array}{c}\text { RHA } \\
7.5 \%\end{array}$ & $\begin{array}{c}\text { CEMIEN } \\
\text { T 92.5\% }\end{array}$ & $\begin{array}{c}\text { FINE } \\
\text { AGGREGATE }\end{array}$ & $\begin{array}{c}\text { COARSE } \\
\text { AGGREGATE }\end{array}$ & $\begin{array}{c}\text { S.P } \\
(1.25 \%)\end{array}$ & $\begin{array}{c}\text { TOTAL } \\
\text { PRICE }\end{array}$ \\
\hline QUANTITY & 28.687 & 353.81 & 482.46 & 1394.06 & 4.245 & 5362.02 \\
PRICE RS. & 0 & 3002 & 590.12 & 1600.10 & 169.8 & INRRUP EES \\
\hline
\end{tabular}

PRICE FOR 1 M3 WITHOUT RHA $=5783.47$ RUPEES PRICE FOR 1 M3 WITH RHA =5362.02. RUPEES TOTAL SAVING= 421.45 RUPEES (7.287\%)

\section{CONCLUSION \\ EXPERIMENTAL INVESTIGATIONS ON STRENGTH}

\section{CUBE COMPRESSIVE STRENGTH}

At the age of 7 days the compressive strength of concrete mixes containing rice husk ash was less than that of mixes without rice husk ash. But at the age of 28 days the compressive strength of concrete mixes containing rice husk ash was more than that of mixes without rice husk ash. This indicates that addition of rice husk ask as partial replacement to cement causes an increase in strength at the age of 28 days of curing. Thus rice husk ash act as pozzolanic material. Hence the compressive strength of concrete increases as the 
percentage of those mineral admixtures increases. The 7 days compressive strength of the concrete mixes containing rice husk ash slightly decreases. Cement replacement level of $7.5 \%$ by rice husk ash in concrete mixes was found to be the optimum level to obtain maximum compression strength at the age of 28 days at $w / c$ ratio 0.40 . At the age of 28 days compressive strength of rice husk ash concrete increase. This indicates that addition of rice husk ash as the partial replacement of cement causes increase strength.

\section{SPLITTING TENSILE STRENGTH}

The optimum replacement of cement by rice husk ash for rice husk ash concrete was found to be 7.5 percent respectively for achieving maximum splitting tensile strength at the age of 28 days at $w / c$ ratio 0.40 . The tensile strength increases along with increase in compressive strength at the age of 28 days.

\section{FLEXURAL STRENGTH}

The optimum replacement of cement by rice husk ash for rice husk ash concrete was found to be 7.5 percent for achieving maximum value of flexural strength at the age of 28 days at $\mathrm{w} / \mathrm{c}$ ratio 0.40 . The flexural strength increases along with increase in compressive strength.

\section{EXPERIMENTAL SETTING TIMES \\ INVESTIGATIONS ON} In the present investigation the setting times of cement pastes, with partial replacement of cement by rice husk ash varying from $0 \%$ to $15 \%$, are in the range conforming to IS 12269 . The setting times of cement paste slightly increases with $5 \%$ to $12.5 \%$ replacement of cement by rice husk ash. There will be no adverse effect on the cement paste containing rice husk ash in cement. The rice husk ash can be used as cementitious material in concrete as it barely affects the initial and the final setting times of cement paste, and the results remain in range specified in IS code 12269.

\section{COST}

In this thesis the replacing of cement by rice husk (RHA) about $7.5 \%$, the overall cost of the work is decreased by $7.287 \%$. It is the excellent opportunity to make the concrete at low price and the cost of construction will be low.

\subsubsection{ENVIRONMENTAL IMPLICATIONS OF USING RHA}

The production and use of RHA in India should be considerably increased given the fact that RHA contributes significantly to a green building. It not only reduces the consumption of cement due to blending but also solves the waste disposal problem.

\section{FUTURE SCOPE}

The following are the suggestions for future work

1. This experimental work focused only a particular type of cement replacement materials. Hence, investigations can be made on different types of cement replacement materials (Blast furnace slag, silica fume, fly ash and metakaoline) to study the strength and durability- related properties.

2. Studies could be conducted for other properties such as creep, shrinkage, carbonation resistance, microstructure etc.

3. Investigations may be carried out for pre-stressed concrete.

4. The effect of rice husk ash addition in high strength concrete exposed to high temperature should be investigated.

\section{CODES}

1. IS 383-1970 Specification for Coarse and Fine Aggregates from Natural Sources for Concrete.

2. IS: 456-2000 Plain and Reinforced Concrete.

3. IS: 9103-1999 Concrete Admixtures Specification.

4. IS: 516-1959 Methods of Tests for Strength of Concrete.

5. IS: 9399-1979 Specification For Apparatus For Flexural Testing Of Concrete.

6. IS: 10086-1982 Specification For Moulds For Use In Tests Of CementAnd Concrete.

7. IS: 12269: 2013 Ordinary Portland Cement- 53 Grade-Specifications.

8. IS: 10262-1982 Recommended Guideline For Concrete Mix Design.

9. BS 1881: Part 122: 1983 Method for determination of water absorption.

\section{REFERENCES}

1. Chai Jaturapitakkull and Boonmark Roongreung: Cementing Material from Calcium Carbide Residue-Rice Husk Ash.(2003)

2. Gemma Rodri'guez de Sensale: Strength development of concrete with rice- husk ash.(2005) 
International Journal of Trend in Scientific Research and Development (IJTSRD) ISSN: 2456-6470

3. Deepa G. Nair, K.S. Jagadish, Alex Fraaij: Reactive pozzolanas from rice husk ash: An alternative to cement for rural housing.(2006)

4. Gemma Rodríguez de Sensale: Effect of rice-husk ash on durability of cementitious materials.(2010)

5. V. Ramasamy: Compressive Strength and Durability Properties of Rice Husk Ash Concrete.(2011)

6. Hwang Chao-Lung, Bui Le Anh-Tuan, Chen Chun-Tsun: Effect of rice husk ash on the strength and durability characteristics of concrete.(2011)

7. Rahmat Madandoust, Malek Mohammad Ranjbar, Hamed Ahmadi Moghadamb, Seyed Yasin Mousavi: Mechanical properties and durability assessment of rice husk ash concrete.(2011)

8. M.F.M. Zain, M.N. Islam, F. Mahmud, M. Jamil: Production of rice husk ash for use in concrete as a supplementary cementitious material.(2011)

9. R.N. Krishna: Rice husk ash - an ideal admixture for concrete in aggressive environments.(2012)

10. S. BAHRI, H. B. MAHMUD: Rice Husk Ash An Alternative Material to Silica Fume for Production of $100 \mathrm{MPa}$ Mortar. (2013)

11. Ha Thanh Le, Sang Thanh Nguyen, and HorstMichael Ludwig: A Study on High Performance Fine-Grained Concrete Containing Rice Husk Ash.(2014) 